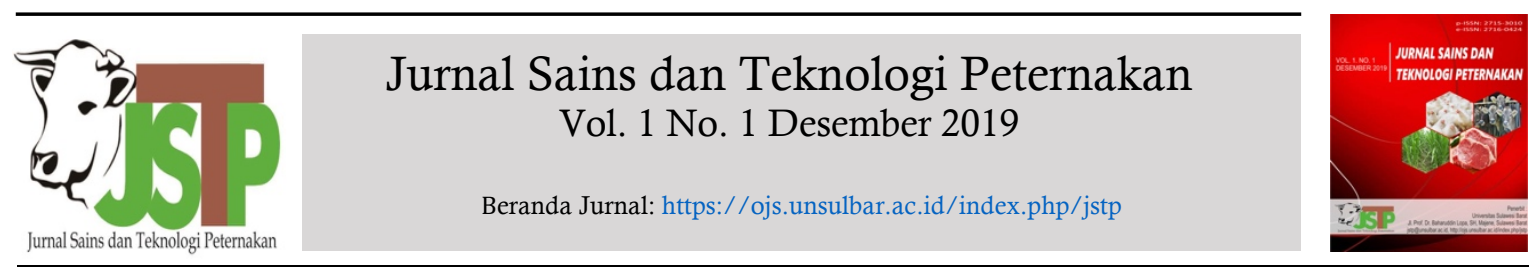

\title{
Kualitas Kimia Daging Ayam Broiler dengan Suhu Pemeliharaan yang Berbeda
}

\section{(Chemical Quality of Broiler Chicken Meat at Different Breeding Temperature)}

Siskha Nurul Hidayah ${ }^{1^{*}}$, Hanny Indrat Wahyuni ${ }^{1}$, Sri Kismiyati ${ }^{1}$

${ }^{1}$ Departemen Peternakan, Fakultas Peternakan dan Pertanian, Universitas Diponegoro Jl. Prof. Soedarto No. 50275, Tembalang, Kota Semarang, Jawa Tengah 50275

\section{A R T I C LE IN F O}

Received: 15 Juli 2019

Accepted: 12 Oktober 2019

*Corresponding author siskha.hida13@gmail.com

Keywords:

Broiler

Meat

Chemical quality

Rearing temperature
Kata Kunci:

Broiler

Daging

Kualitas kimia

Perbedaan suhu

pemeliharaan

\section{A B S T R A C T}

The aim of this study is to prove the influence of different rearing temperature on the chemical quality of broiler chickens meat. Twenty birds of male broiler chicken CP 707 strain age 21 days was used in this study. The average body weight was $1167 \pm 0,17 \mathrm{~g}$. The research used t-test with 2 treatments and 10 replications. The treatments applied was rearing temperature: high $\left(35-36{ }^{\circ} \mathrm{C}, \mathrm{T} 1\right)$ and standart $\left(23-24{ }^{\circ} \mathrm{C}, \mathrm{T} 2\right)$ from age $21-35$ days. The variables observed were moisture, ash, fat and protein content of thebreast meat. The results showed that different rearing temperature did not significantly affected on the moisture and ash content, but significantly affected on the fat and protein content of broiler breast meat $(\mathrm{P}<0.05)$. The conclusions of this study was proved that high rearing temperature $\left(35-36^{\circ} \mathrm{C}\right)$ from 21 to 35 days of age caused a decreased in protein content and an increased in fat content of breast broiler chickens meat, however, the moisture and ash content remained similar.

\section{A B S T R A K}

Penelitian bertujuan untuk membuktikan pengaruh perbedaan suhu pemeliharaan terhadap kualitas kimia daging ayam broiler. Materi yang digunakan pada penelitian ini adalah ayam broiler strain $\mathrm{CP}$ 707 jantan periode finisher (umur 21 hari) sebanyak 20 ekor dengan rataan bobot badan $1167 \pm 0,17 \mathrm{~g}$. Penelitian menggunakan uji-t dengan 2 perlakuan dan 10 ulangan. Perlakuan yang diterapkan adalah pemeliharaan suhu tinggi $\left(35-36^{\circ} \mathrm{C}, \mathrm{T} 1\right)$ dan pemeliharaan suhu standar $\left(23-24^{\circ} \mathrm{C}\right.$, T2) dari umur 21-35 hari. Kualitas kimia daging yang diamati adalah kadar air, kadar abu, kadar lemak dan kadar protein daging bagian dada. Hasil penelitian menunjukkan bahwa suhu pemeliharaan tidak berpengaruh terhadap kadar air dan kadar abu daging ayam broiler, tetapi berpengaruh nyata terhadap kadar lemak dan kadar protein daging dada ayam broiler $(\mathrm{P}<0,05)$. Pemeliharaan suhu tinggi $\left(35-36^{\circ} \mathrm{C}\right)$ dari umur $21-35$ hari menyebabkan penurunan kadar protein dan peningkatan kadar lemak daging dada ayam broiler, tetapi kadar air dan kadar abu daging ayam broiler tetap sama.

CJurnal Sains dan Teknologi Peternakan Vol 1(1) Desember 2019 p-ISSN: 2715-3010 | e-ISSN: 2716-0424 


\section{Pendahuluan}

Seiring dengan perkembangan jaman diikuti peningkatan jumlah penduduk dan sumber daya manusia (SDM), serta kesadaran akan pemenuhan gizi seimbang, menimbulkan peningkatan konsumsi sumber protein hewani seperti daging. Hal ini menyebabkan kebutuhan daging semakin meningkat terutama daging ayam, mengingat harga daging ayam lebih terjangkau oleh masyarakat dibanding daging ruminansia. Konsumen lebih menyukai daging ayam dikarenakan mudah didapat, harga yang terjangkau, memiliki kandungan gizi yang tinggi dan aroma yang tidak anyir, warna yang segar serta memiliki tekstur yang lebih lunak (Ilham et al., 2018)

Ayam tergolong ternak berdarah panas yang suhu tubuhnya diatur dalam batasan yang sesuai, suhu pemeliharaan yang tinggi dapat mengakibatkan stress (Tamzil, 2014). Suhu optimal dalam pemeliharaan ayam broiler yaitu $23-24^{\circ} \mathrm{C}$ (Zhang et al., 2012).

Suhu lingkungan Indonesia yang beriklim tropis menurut Purwantara (2015) berada pada rata $27-28^{\circ} \mathrm{C}$. Suhu tersebut tidak sesuai untuk pemeliharaan ayam broiler karena dapat menyebabkan cekaman panas.

Stress panas yang dialami oleh ayam broiler menyebabkan produktivitas menurun karena konsumsi pakan rendah dan bobot badan menurun (Prayitno \& Sugiharto, 2015). Anggitasari, Sjofjan, \& Djunaidi (2016) menyatakan bahwa ayam broiler yang mengalami penurunan konsumsi pakan akan berdampak pada bobot badan dan bobot karkas yang menurun, hal tersebut menyebabkan penurunan pada komposisi kimia daging. Zhang et al. (2012) melaporkan bahwa ayam broiler yang dipelihara pada suhu $35-36{ }^{\circ} \mathrm{C}$ mengakibatkan penurunan performa dan komposisi kimia daging ayam broiler, meliputi kadar air, kadar protein, kadar lemak dan kadar abu di dalam daging. Komposisi kimia sering digunakan untuk mengukur kualitas kimia daging.

Tujuan dari penelitian ini adalah membuktikan pengaruh perbedaan suhu pemeliharaan terhadap kualitas kimia daging ayam broiler yang meliputi kadar air, kadar abu, kadar lemak dan kadar protein di dalam daging ayam broiler yang dipelihara pada suhu tinggi dan suhu standar.

\section{Materi dan Metode}

\subsection{Bahan}

Bahan yang digunakan dalam penelitian adalah ayam broiler jantan strain CP 707 periode finisher (umur 21 hari) sebanyak 20 ekor dengan rata-rata bobot badan $1.167 \mathrm{~g}$ standar deviasi $0,17(\mathrm{CV}=2,936 \%)$ yang diperoleh dari kandang closed house, Fakultas Peternakan dan Pertanian, Universitas Diponegoro, Semarang. Ayam dimasukkan ke dalam dua kandang yang berukuran $1,35 \times 1,35 \times 1,35 \mathrm{~m}$ dengan masingmasing ruangan berisi 10 ekor ayam broiler. Pakan yang digunakan adalah pakan komersial 512B dengan kandungan nutrisi disajikan pada Tabel 1.

Tabel 1. Kadar nutrisi pakan ayam broiler periode finisher

\begin{tabular}{lc}
\hline Nutrien & Kadar (\%) \\
\hline Air & 11,20 \\
Abu & 6,86 \\
Lemak Kasar & 3,96 \\
Protein Kasar & 21,27 \\
Serat Kasar & 4,19 \\
\hline Sumber: & Analisis proksimat laboratorium Ilmu Nutrisi dan \\
& Pakan, Universitas Diponegoro, Semarang (2018).
\end{tabular}

\subsection{Alat}

Alat yang digunakan adalah papan tripleks untuk menyekat kandang, AC yang digunakan untuk pendingin kandang, thermostat untuk pengatur suhu didalam kandang, heater yang terdiri dari 6 lampu bohlam 60 watt, thermohygrometer untuk mengukur suhu dan kelembaban, tempat pakan sebanyak 4 buah dan tempat minum sebanyak 4 buah, desinfektan untuk mendesinfeksi kandang, koran sebagai alas kandang yang di atasnya ditaburi sekam sebagai litter, blower untuk membantu sirkulasi udara, timbangan gantung [C-tech Portable Electronic Scale] kapasitas $50 \mathrm{~kg}$ dan ketelitian $100 \mathrm{~g}$ untuk menimbang bobot badan ayam broiler, timbangan digital $\left[\mathrm{SF}-400^{\circledR}\right]$ kapasitas $7 \mathrm{~kg}$ dengan ketelitian $1 \mathrm{~g}$ untuk menimbang pakan.

\subsection{Metode}

Penelitian dilakukan dengan merancang suhu pemeliharaan agar mencapai suhu panas dengan cara menyalakan 6 lampu pijar 60 watt pada pukul 05.00 pagi agar suhu naik secara bertahap mencapai $35-36{ }^{\circ} \mathrm{C}$ pada pukul 07.00 pagi kemudian suhu perlakuan akan diatur otomatis pada suhu $36{ }^{\circ} \mathrm{C}$ menggunakan thermostat, ketika mencapai suhu $36^{\circ} \mathrm{C}$ lampu pijar akan mati dan jika suhu kurang dari $36^{\circ} \mathrm{C}$ maka lampu pijar akan tetap menyala. Penggunaan blower akan membantu sirkulasi udara terutama pada siang hari, sedangkan perlakuan suhu nyaman dengan cara 
menyalakan AC yang diatur suhu yang paling rendah $\left(16{ }^{\circ} \mathrm{C}\right)$ kemudian bertahap dinaikkan mengikuti suhu lingkungan sehingga pada pukul 07.00 pagi suhunya sekitar $23-24^{\circ} \mathrm{C}$. Semakin siang suhu lingkungan semakin meningkat, sehingga suhu AC akan diturunkan kembali untuk mempertahankan suhu nyaman.

Perlakuan yang diberikan adalah: T1: Suhu panas $\left(35-36{ }^{\circ} \mathrm{C}\right)$ dan T2: Suhu nyaman $(23-$ $24{ }^{\circ} \mathrm{C}$ ) dengan masing-masing 10 ulangan. Penelitian dibagi menjadi dua tahap, yaitu tahap persiapan dan pemeliharaan. Tahap persiapan terdiri dari persiapan kandang meliputi pembuatan sekat di dalam ruangan yang akan digunakan sebagai kandang pemeliharaan yang berukuran $1,35 \times 1,35 \mathrm{~m}^{2}$ dan pembersihan kandang menggunakan detergen kemudian setelah kering ditaburi dengan kapur. Alat pendingin (AC) dipasang di salah satu ruangan yang digunakan sebagai kandang untuk suhu standar, thermohygrometer dan heater ditaruh di dalam masing-masing kandang, termostat dipasang di kandang yang lain, yaitu kandang dengan suhu di atas standar. Semua kandang dilengkapi dengan tempat pakan dan tempat minum, dilapisi koran kemudian di atasnya ditaburi sekam untuk alas kandang. Ayam broiler ditimbang untuk dipilih yang bobot badannya seragam dan jenis kelamin sama (jantan) yang didatangkan dari kandang closed house, Fakultas Peternakan dan Pertanian, Universitas Diponegoro, Semarang.

Tahap pemeliharaan dilakukan selama dua minggu dengan diberi perlakuan suhu pemeliharaan, dimana 10 ekor dipelihara pada suhu tinggi $\left(35-36^{\circ} \mathrm{C}\right)$ dan 10 ekor yang lainnya dipelihara pada suhu standar $\left(23-24^{\circ} \mathrm{C}\right)$. Pakan dan air minum diberikan secara ad libitum. Sekam diganti setiap hari. Perlakuan diterapkan setiap hari selama 12 jam dimulai dari pukul 07.00 sampai dengan pukul 19.00 WIB. Heater dan AC dimatikan setelah pukul 19.00, namun lampu penerangan tetap menyala. Suhu dan kelembaban di kedua kandang dicatat pada pukul 07.00 pagi, pukul 13.00 siang dan pukul 19.00 malam. Suhu dan kelembaban di luar kandang juga dicatat secara bersamaan.

Pengambilan data dilakukan pada akhir pemeliharaan saat ayam berumur 35 hari (5 minggu). Ayam broiler dari setiap perlakuan ditimbang terlebih dahulu untuk diperoleh bobot akhir, kemudian disembelih, dilakukan pencabutan bulu, mengeluarkan jeroan, untuk mendapatkan karkas. Sampel daging diambil pada bagian dada sebanyak $50 \mathrm{~g}$ dan di analisis proksimat untuk diketahui komposisi kimia daging.
Kualitas kimia daging yang diamati pada penelitian ini meliputi kadar air, abu, protein dan lemak. Kandungan kimia daging tersebut dianalisis proksimat dengan prosedur dalam SNI 01-2891-1992 (Badan Standardisasi Nasional Indonesia, 1992) di Laboratorium Terpadu Universitas Diponegoro, Semarang.

\subsection{Analisis Data}

Data yang diperoleh dianalisis menggunakan uji t-test independent sample.

\section{Hasil dan Pembahasan}

Hasil analisis kimia daging ayam broiler yang dipelihara pada suhu tinggi dan standar pada umur 21-35 hari disajikan pada Tabel 2. Analisis statistik menunjukkan bahwa kadar air dan kadar abu daging ayam broiler tidak dipengaruhi oleh suhu pemeliharaan yang berbeda, sedangkan kadar protein dan kadar lemak nyata dipengaruhi oleh suhu pemeliharaan yang berbeda $(\mathrm{P}<0,05)$.

Tabel 2. Rerata proksimat daging ayam broiler yang dipelihara pada suhu tinggi dan suhu standar selama 2 minggu

\begin{tabular}{|c|c|c|c|}
\hline \multirow{2}{*}{ Parameter } & \multicolumn{2}{|c|}{ Suhu pemeliharaan } & \multirow{2}{*}{ Uji t } \\
\hline & $35-36^{\circ} \mathrm{C}$ & $23-24^{\circ} \mathrm{C}$ & \\
\hline & \multicolumn{2}{|c|}{ 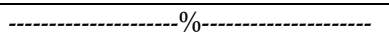 } & \\
\hline Kadar air & $70,51 \pm 0,19$ & $70,91 \pm 0,29$ & Ns \\
\hline Kadar abu & $0,82 \pm 0,44$ & $1,04 \pm 0,79$ & Ns \\
\hline Kadar protein & $21,18 \pm 0,64^{b}$ & $22,55 \pm 0,71^{\mathrm{a}}$ & S \\
\hline Kadar lemak & $1,15 \pm 0,49^{a}$ & $0,58 \pm 0,38^{b}$ & S \\
\hline
\end{tabular}

Keterangan: Superskrip yang berbeda pada baris yang sama menunjukkan perbedaan yang nyata $\mathrm{P}<0,05$. Ns: Tidak nyata; S: Nyata.

\subsection{Kadar Air}

Kadar air daging yang mendapat perlakuan suhu pemeliharaan yang tinggi $\left(35-36{ }^{\circ} \mathrm{C}\right)$ sebesar 70,51\% standar deviasi 0,44 sedangkan pada perlakuan suhu pemeliharaan standar (23$24{ }^{\circ} \mathrm{C}$ ) sebesar 70,91 \% Standar deviasi 0,54. Suhu pemeliharaan yang berbeda pada penelitian ini, tidak mengubah kadar air daging ayam broiler.

Berbeda dengan penelitian Zhang et al., (2012) yang menyimpulkan bahwa kadar air daging yang lebih tinggi ditunjukkan oleh ayam broiler yang dipelihara suhu $34^{\circ} \mathrm{C}$ dari umur $4-$ 6 minggu. Perbedaan hasil penelitian tersebut disebabkan oleh lama pemeliharaan yang berbeda sehingga terdapat perbedaan metabolisme, bobot badan dan komposisi kimia daging ayam broiler. Menurut Syamsuryadi, Afnan, Arief, \& Ekastuti (2017) kadar air daging ayam broiler berbanding lurus dengan bobot badan ayam broiler, ayam broiler yang dipelihara 
selama 15 - 42 hari pada suhu $29,85^{\circ} \mathrm{C}$ dengan bobot badan $2.234 \mathrm{~g}$ /ekor diperoleh kadar air sebesar 69,47 \% standar deviasi 1,02 dan bobot badan ayam broiler yang dipelihara pada suhu $25,85{ }^{\circ} \mathrm{C}$ diperoleh kadar air sebesar 69,43\% standar deviasi 0,72 dengan bobot badan 1.889,5 g/ekor.

\subsection{Kadar Abu}

Kadar abu daging yang mendapat perlakuan pemeliharaan pada suhu tinggi (35$36{ }^{\circ} \mathrm{C}$ ) yakni $0,82 \%$ standar deviasi 0,79 , sedangkan pada suhu standar $\left(23-24^{\circ} \mathrm{C}\right)$ sebesar $1,04 \%$ standar deviasi 0,44 . Suhu pemeliharaan yang berbeda tidak mengubah kadar abu daging ayam broiler. Qurniawan, Arief, \& Afnan (2016) menyatakan bahwa kadar abu adalah banyaknya mineral yang terkandung di dalam daging dan akan meningkat seiring dengan pertambahan umur ayam broiler.

Ayam broiler yang dipelihara pada suhu tinggi $\left(35-36^{\circ} \mathrm{C}\right)$ pada penelitian ini juga dimungkinkan banyak mengonsumsi air minum. Hal ini didukung oleh pendapat Ximenes, Trisunuwati, \& Muharlien (2018) yang menyatakan bahwa ayam broiler yang dipelihara pada suhu tinggi akan meningkatkan konsumsi air minum sehingga ekskreta menjadi encer. Hal ini disebabkan karena ayam mengalami stres, sebagaimana ditunjukkan pada nilai heat stress index (HSI) pada pemeliharaan suhu tinggi yaitu sebesar 171,76 (Tabel 3). Rahul \& Pramod, (2016) menyatakan bahwa angka HSI yang masih dapat diterima oleh ayam broiler adalah 160.

Tabel 3. Heat stress index ayam broiler yang dipelihara pada suhu tinggi

\begin{tabular}{|c|c|c|c|c|c|c|c|c|c|c|c|c|c|}
\hline \multirow[b]{2}{*}{ Perlakuan } & \multirow[b]{2}{*}{ Tanggal } & \multicolumn{3}{|c|}{ Jam 07.00} & \multirow[b]{2}{*}{ HSI } & \multicolumn{3}{|c|}{ Jam 07.00} & \multirow[b]{2}{*}{ HSI } & \multicolumn{3}{|c|}{ Jam 07.00} & \multirow[b]{2}{*}{ HSI } \\
\hline & & $\mathrm{T}\left({ }^{\circ} \mathrm{C}\right)$ & $\begin{array}{l}\mathrm{RH} \\
(\%)\end{array}$ & $\mathrm{T}\left({ }^{\circ} \mathrm{F}\right)$ & & $\mathrm{T}\left({ }^{\circ} \mathrm{C}\right)$ & $\begin{array}{l}\mathrm{RH} \\
(\%)\end{array}$ & $\mathrm{T}\left({ }^{\circ} \mathrm{F}\right)$ & & $\mathrm{T}\left({ }^{\circ} \mathrm{C}\right)$ & $\begin{array}{l}\mathrm{RH} \\
(\%)\end{array}$ & $\mathrm{T}\left({ }^{\circ} \mathrm{F}\right)$ & \\
\hline & $08 / 03 / 18$ & 23,2 & 94 & 95,18 & 175,18 & 36,1 & 65 & 96,98 & 161,98 & 35,3 & 72 & 95,54 & 167,54 \\
\hline & $09 / 03 / 18$ & 22,6 & 86 & 95,00 & 174,00 & 36,2 & 60 & 97,16 & 157,16 & 35,1 & 75 & 95,18 & 170,18 \\
\hline & $10 / 03 / 18$ & 23,2 & 86 & 94,82 & 173,82 & 35,7 & 60 & 96,26 & 156,26 & 35,3 & 78 & 95,54 & 173,54 \\
\hline & $11 / 03 / 18$ & 22,8 & 90 & 95,00 & 178,00 & 35,9 & 64 & 96,62 & 160,62 & 35,4 & 75 & 95,72 & 170,72 \\
\hline & $12 / 03 / 18$ & 23,1 & 88 & 95,54 & 173,54 & 36,3 & 60 & 97,34 & 157,34 & 35,2 & 75 & 95,36 & 170,36 \\
\hline & $13 / 03 / 18$ & 23,1 & 88 & 95,00 & 178,00 & 35,8 & 65 & 96,44 & 161,44 & 35,5 & 78 & 95,90 & 173,90 \\
\hline & $14 / 03 / 18$ & 24,1 & 90 & 95,36 & 175,36 & 36,1 & 62 & 96,98 & 158,98 & 35,4 & 76 & 95,72 & 171,72 \\
\hline Suhu & $15 / 03 / 18$ & 23,9 & 92 & 95,18 & 174,18 & 35,9 & 62 & 96,62 & 158,62 & 35,4 & 76 & 95,72 & 171,72 \\
\hline \multirow[t]{8}{*}{ tinggi } & $16 / 03 / 18$ & 23,3 & 86 & 95,00 & 175,00 & 35,7 & 67 & 96,26 & 163,26 & 35,6 & 79 & 96,08 & 175,08 \\
\hline & $17 / 03 / 18$ & 23,9 & 92 & 94,82 & 174,82 & 36,0 & 68 & 96,80 & 164,80 & 35,1 & 75 & 95,18 & 170,18 \\
\hline & $18 / 03 / 18$ & 23,7 & 87 & 95,36 & 173,36 & 36,1 & 61 & 96,98 & 157,98 & 35,8 & 78 & 96,44 & 174,44 \\
\hline & $19 / 03 / 18$ & 23,7 & 90 & 95,36 & 171,36 & 36,1 & 60 & 96,98 & 156,98 & 35,6 & 76 & 96,08 & 172,08 \\
\hline & $20 / 03 / 18$ & 23,8 & 85 & 95,00 & 174,00 & 36,3 & 63 & 97,34 & 160,34 & 35,8 & 75 & 96,44 & 171,44 \\
\hline & $08 / 03 / 18$ & 23,4 & 23,4 & 95,12 & 174,66 & 36,0 & 63 & 96,83 & 159,67 & 35,4 & 76 & 95,76 & 171,76 \\
\hline & $09 / 03 / 18$ & 23,2 & 94 & 95,18 & 175,18 & 36,1 & 65 & 96,98 & 161,98 & 35,3 & 72 & 95,54 & 167,54 \\
\hline & $10 / 03 / 18$ & 22,6 & 86 & 95,00 & 174,00 & 36,2 & 60 & 97,16 & 157,16 & 35,1 & 75 & 95,18 & 170,18 \\
\hline Rataan & & 23,4 & 23,4 & 95,12 & 174,66 & 36,0 & 63 & 96,83 & 159,67 & 35,4 & 76 & 95,76 & 171,76 \\
\hline
\end{tabular}

Keterangan: HSI: Heat Stress Index. T: Temperatur; RH: Kelembaban

Ayam broiler yang dipelihara pada suhu tinggi mengalami akan mengalami stres dan untuk mengurangi panas di dalam tubuh maka ayam melakukan evaporasi melalui pernafasan atau panting. Kondisi ini juga diantisipasi oleh ayam dengan meningkatkan konsumsi air minum. Sulistyoningsih \& Rakhmawati (2018) menyatakan bahwa fungsi utama dalam peningkatan konsumsi air pada ayam broiler yang berada dalam kondisi stres panas adalah untuk mengganti air yang hilang di dalam tubuh ayam akibat thermoregulasi yang dilakukan oleh ayam melalui evaporasi. Namun demikian kehilangan cairan tubuh pada ayam broiler tersebut tidak menyebabkan kualitas daging menurun terutama dilihat dari kadar air dan kadar abunya, karena keduanya masih mempunyai kualitas yang sama.

\subsection{Kadar Protein}

Kadar protein daging pada ayam broiler yang mendapat perlakuan suhu pemeliharaan tinggi $\left(35-36{ }^{\circ} \mathrm{C}\right)$ sebesar $21,18 \%$ standar deviasi 0,64 sedangkan kadar protein ayam broiler yang mendapat perlakuan suhu pemeliharaan standar $\left(23-24^{\circ} \mathrm{C}\right)$ sebesar 22,55 $\%$ standar deviasi 0,71 . Suhu pemeliharaan yang berbeda berpengaruh nyata terhadap kadar protein daging ayam broiler $(\mathrm{P}<0,05)$. Kadar protein daging ayam broiler yang dipelihara pada suhu tinggi $\left(35-36{ }^{\circ} \mathrm{C}\right)$ lebih rendah dibandingkan dengan kadar protein daging ayam broiler yang dipelihara pada suhu standar (23 $24^{\circ} \mathrm{C}$ ). Liu et al. (2015) menyatakan bahwa kadar protein daging ayam broiler dipengaruhi oleh konsumsi pakan karena jumlah pakan yang dikonsumsi menentukan jumlah protein yang dideposisi di dalam daging. 
Ayam broiler yang dipelihara pada suhu tinggi mengalami penurunan konsumsi pakan, hal ini dilakukan untuk mengurangi panas di dalam tubuh. Konsumsi pakan yang turun menyebabkan rendahnya konsumsi protein dan bobot badan akan terhambat. Tamzil (2014) menyatakan bahwa suhu yang tinggi menyebabkan ayam broiler mengalami penurunan konsumsi pakan dan meningkatkan konsumsi air.

Rotiah, Widiastuti, \& Sunarti (2019) menyatakan total konsumsi pakan ayam broiler yang dipelihara dengan suhu tinggi $\left(35-36{ }^{\circ} \mathrm{C}\right)$ lebih rendah yaitu 1.049,7 g/ekor, dibandingkan dengan total konsumsi pakan ayam broiler yang dipelihara pada suhu standar $\left(23-24^{\circ} \mathrm{C}\right)$ yaitu sebesar 1.602,25 g/ekor. Sari, Sukamto, \& Dwiloka (2014) menyatakan bahwa konsumsi protein berkaitan dengan konsumsi pakan, yang berarti jumlah konsumsi pakan menentukan besarnya konsumsi protein. Hal ini yang menyebabkan kadar protein daging ayam broiler yang dipelihara pada suhu tinggi menjadi rendah.

Rotiah, Widiastuti, \& Sunarti (2019) menyatakan bobot badan ayam broiler yang dipelihara pada suhu $35-36{ }^{\circ} \mathrm{C}$ lebih rendah dibandingkan ayam broiler yang dipelihara pada suhu $23-24{ }^{\circ} \mathrm{C}$. Bobot badan yang rendah berhubungan dengan konsumsi pakan, konsumsi pakan berbanding lurus dengan konsumsi protein, yang berarti jika konsumsi pakan rendah mengakibatkan konsumsi protein rendah, sedangkan dibutuhkan konsumsi protein yang cukup untuk pertumbuhan dan pertambahan bobot badan. Hal ini sesuai dengan pendapat Ximenes, Trisunuwati, \& Muharlien (2018) yang menyatakan bahwa konsumsi pakan yang menurun akan berdampak pada penurunan bobot badan dikarenakan kurangnya asupan nutrisi sehingga pertumbuhan ayam akan terganggu.

Kondisi pada ayam broiler ini adalah stress akibat suhu dan kelembaban yang di luar zona nyamannya dan dapat diukur menggunakan HSI. Angka HSI pada ayam yang dipelihara pada suhu tinggi $\left(35-36^{\circ} \mathrm{C}\right)$ sebesar 171,76 . Hasil penelitian Palupi (2015) menyatakan bahwa angka HSI di atas 160 akan menyebabkan penurunan konsumsi pakan dan performans ayam broiler, yang berdampak pada penurunan kadar protein daging sebagaimana yang diamati pada penelitian ini.

\subsection{Kadar Lemak}

Kadar lemak daging ayam broiler yang mendapat perlakuan pemeliharaan pada suhu tinggi $\left(35-36{ }^{\circ} \mathrm{C}\right)$ yakni $1,15 \%$ dengan standar deviasi 0,49 sedangkan pada suhu standar (23$24{ }^{\circ} \mathrm{C}$ ) sebesar $0,58 \%$ dengan standar deviasi 0,38 . Hasil ini menunjukkan bahwa kadar lemak berada di bawah normal. Suhu pemeliharaan yang berbeda berpengaruh nyata pada kadar lemak daging ayam broiler. Kadar lemak berbanding terbalik dengan kadar protein. Kadar lemak daging ayam broiler yang dipelihara dengan suhu $35-36{ }^{\circ} \mathrm{C}$, lebih tinggi dibandingkan dengan kadar lemak daging ayam broiler yang dipelihara pada suhu $23-24^{\circ} \mathrm{C}$, diikuti kadar protein daging ayam broiler yang dipelihara dengan suhu $35-36{ }^{\circ} \mathrm{C}$ yang lebih rendah. Hal ini sesuai dengan pendapat Hartono, Iriyanti, \& Santosa (2013) yang menyatakan bahwa kandungan lemak berkorelasi negatif dengan kadar protein, semakin tinggi kadar lemak daging ayam maka semakin berkurang kadar protein daging begitupun sebaliknya.

\section{Kesimpulan}

Penelitian ini membuktikan bahwa ayam broiler yang dipelihara pada suhu tinggi $(35-36$ $\left.{ }^{\circ} \mathrm{C}\right)$ menyebabkan penurunan kadar protein dan peningkatan kadar lemak daging ayam broiler sedangkan ayam broiler yang dipelihara pada suhu standar $\left(23-24{ }^{\circ} \mathrm{C}\right)$ kadar protein lebih tinggi dan kadar lemak daging ayam broiler lebih rendah, tetapi kadar air dan kadar abunya tetap sama.

\section{Daftar Pustaka}

Anggitasari, S., Sjofjan, O., \& Djunaidi, I. H. (2016). Pengaruh beberapa jenis pakan komersial terhadap kinerja produksi kuantitatif dan kualitatif ayam pedaging. Buletin Peternakan, 40(3), 187-196. https://doi.org/10.21059/buletinpeternak .v40i3.11622

Badan Standardisasi Nasional Indonesia. (1992). Cara Uji Makanan dan Minuman: SNI 012891-1992. In BSNI.

Hartono, E., Iriyanti, N., \& Santosa, R. S. S. (2013). Penggunaan pakan fungsional terhadap daya ikat air, susut masak, dan keempukan daging ayam Broiler. Jurnal Ilmiah Peternakan, 1(1), 10-19.

Ilham, M., Fitra, D., \& Suryani, P. (2018). Preferensi konsumen dalam memilih daging ayam broiler di pasar tradisional Kecamatan Kampar, Kabupaten Kampar, Provinsi Riau. Prosiding Seminar Nasional Teknologi Peternakan Dan Veteriner 2017, 
491-499.

Liu, S. K., Niu, Z. Y., Min, Y. N., Wang, Z. P., Zhang, J., He, Z. F., Li, H. L., Sun, T. T., \& Liu, F. Z. (2015). Effects of dietary crude protein on the growth performance, carcass characteristics and serum biochemical indexes of Lueyang black-boned chickens from seven to twelve weeks of age. Brazilian Journal of Poultry Science, 17(1), 103-108. https://doi.org/10.1590/1516635x1701103-108

Palupi, R. (2015). Manajemen mengatasi heat stess pada ayam Broiler yang dipelihara dilahan kering. Prosiding Seminar Nasional Lahan Suboptimal, 275-283.

Prayitno, D. S., \& Sugiharto. (2015). Kesejahteraan dan Metode Penelitian Tingkah Laku Unggas. Badan Penerbit Universitas Diponegoro.

Purwantara, S. (2015). Studi temperatur udara terkini di wilayah di Jawa Tengah dan DIY. Geomedia: Majalah Ilmiah Dan Informasi Kegeografian, 13(1), 41-52. https://doi.org/10.21831/gm.v13i1.4476

Qurniawan, A., Arief, I. I., \& Afnan, R. (2016). Performans produksi ayam pedaging pada lingkungan pemeliharaan dengan ketinggian yang berbeda di Sulawesi Selatan. Jurnal Veteriner, 17(4), 622-633. https://doi.org/10.19087/jveteriner.2016. 17.4.622

Rahul, R., \& Pramod, K. (2016). Heat stress management practices in poultry. International Journal for Scientific Research and Development, 4(2), 76-79.

Rotiah, Widiastuti, E., \& Sunarti, D. (2019). Relative weight of small intestine and lymphoid organ of finisher period Broiler chicken at different rearing temperatures. Journal of Animal Research Applied Sciences, 1(1), 6-10.

Sari, K. A., Sukamto, B., \& Dwiloka, B. (2014). Efisiensi penggunaan protein pada ayam Broiler dengan pemberian pakan mengandung tepung daun kayambang (Salvinia molesta). Jurnal Agripet, 14(2), 7683.https://doi.org/10.17969/agripet.v14i2 .1867

Sulistyoningsih, M., \& Rakhmawati, R. (2018). Efektifitas feed additive herbal jahe, kunyit, salam dan pencahayaan terhadap teknik tonic imobility, suhu rektal dan kadar air daging broiler. Jurnal Ilmiah Teknosains,
4(2), 119-128.

Syamsuryadi, B., Afnan, R., Arief, I. I., \& Ekastuti, D. R. (2017). Ayam pedaging jantan yang dipelihara di dataran tinggi Sulawesi Selatan produktivitasnya lebih tinggi. Jurnal Veteriner, 18(1), 160-166. https://doi.org/10.19087/jveteriner.2017. 18.1.160

Tamzil, M. H. (2014). Stres panas pada unggas: metabolisme, akibat dan upaya penanggulangannya. Wartazoa, 24(2), 5766.

Ximenes, L., Trisunuwati, P., \& Muharlien, M. (2018). Performa produksi Broiler starter akibat cekaman panas dan perbedaan awal waktu pemberian pakan. Jurnal Ilmu-Ilmu Peternakan, 28(2), 158-167.

Zhang, Z. Y., Jia, G. Q., Zuo, J. J., Zhang, Y., Lei, J., Ren, L., \& Feng, D. Y. (2012). Effects of constant and cyclic heat stress on muscle metabolism and meat quality of broiler breast fillet and thigh meat. Poultry Science, 91(11), 2931-2937. https://doi.org/10.3382/ps.2012-02255 